DOI https://doi.org/10.30525/978-9934-26-173-2-44

\title{
АКТИВІЗАЦІЯ ФАХОВОЇ ПІДГОТОВКИ СТУДЕНТІВ ЕКОНОМІЧНОГО ВУЗУ
}

\author{
Опольська М. В. \\ кандидат педагогічних наук, \\ дочент кафедри соиіально-гуманітарних дисичилін \\ Університет економіки і підприємництва \\ м. Хмельницький, Украӥна
}

Формування особистості фахівця економічного профілю, який буде працювати в умовах ринкової економіки, це складний і тривалий процес. Забезпечити його ефективність може, на нашу думку, навчальновиховна діяльність викладача, що базується на активних методах навчання і виховання, відображає специфіку професійної діяльності, i яка дозволяє створити необхідну мотивацію цієї діяльності.

У закладах вищої освіти професіоналізація студентів відображається у структурі професійної освіти та різноманітних формах самоосвіти і самовдосконалення особистості. В ній простежуються:

- традиційні форми (лекції, практичні, семінари тощо);

- нетрадиційні (мобільні) форми (імітаційні та не імітаційні: проблемні лекції, тренінги, творчі і проблемні групи, проблемні ситуації, науково-освітні гуртки, конференції, об'єднання за інтересами, освітньо-пізнавальні екскурсії тощо);

- самоосвіта (керована і спонтанна).

Якщо вести мову про можливі методи підвищення рівня ефективності навчального процесу студентів економічного вузу, то вони потребують організації цілеспрямованого впливу на студентів у ході педагогічної діяльності в умовах суб'єкт-суб'єктних відносин шляхом впровадження в навчальний процес активних методів навчання та виховання.

Проблема активізації навчально-виховного процесу 3 підготовки майбутніх суб'єктів економічної діяльності знаходиться в полі зору багатьох дослідників проблем фахової освіти, зокрема, 3. Дичківської, Г. Ковальчука, О. Падалка, Н. Софій, С. Шевчука та ін. Причому, аналіз психолого-педагогічної літератури (Г. Балл, А. Бодальов, В. Дзюба, М. Кашапов, В. Ковальчук, П. Щербань, В. Ягоднікова та ін.) показав, що значна увага приділяється використанню різного типу завдань i ситуацій, що потребують від студентів творчого мислення i самостійного прийняття рішень, мають досить помітне виховне 164 
значення, оскільки дозволяють навчати студентів оцінювати факти, спостерігати за розгортанням певних дій і аналізувати їх, формувати певну принципову позицію. Однак невирішеною залишається проблема організації навчального процесу з узгодженістю та системністю цілей на різних його етапах, що має за мету активізацію інтелектуальної та практичної діяльності студентів у напрямку їх професіоналізації.

У статті визначена роль активних методів навчання в активізації професійної підготовки студентів економічного вузу, зокрема, навчальному процесі з підготовки студентів-менеджерів.

Ми поділяємо думку О. Пєхоти про те, що планування навчального курсу починається 3 визначення програми дій, які спрямовані на досягнення певного результату. Програма повинна здійснюватись у такій послідовності:

- визначення мети навчання;

- врахування особливостей певної групи студентів;

- визначення бажаних результатів (обсягу знань, вмінь та навичок);

- розробка змісту конкретних навчальних тем або курсів, які відповідають меті навчання;

- попередня діагностика визначення загального рівня знань і підготовленості до навчання;

- вибір мети і засобів навчання з конкретної теми;

- координація діяльності студентів;

- оцінювання знань та внесення згідно з їх результатами коректив у навчальний процес [1].

Підкреслимо, що суттєвою особливістю педагогічної процесу $є$ те, що він являє собою процес взаємодії людей, тому зростає роль особистісних відносин у цьому процесі, співпраці і скоординованості зусиль усіх ланок соціалізуючого впливу на особистість, активної i цілеспрямованої участі викладача, що здійснює педагогічний вплив на об'єкт своєї діяльності - особистість студента, формуючи його знання, вміння, навички. Одночасно об’єкт впливу викладача є суб'єктом, оскільки повноцінний навчально-виховний процес неможливий без активності самої особистості, їі самовиховання і самонавчання.

В навчальному процесі Університету економіки і підприємництва реалізація поставленої мети забезпечується програмами дисциплін, що входять до переліку дисциплін професійного циклу підготовки майбутніх менеджерів: «Етика i естетика», «Бізнес-етика», «Конфліктологія», зміст яких є узгодженим в контексті професійної підготовки, а поставлені завдання реалізуються внаслідок застосування активних методів навчання. Так, дисципліна «Етика і естетика» закладає основи гуманістичного аналізу дійсності, що в поєднанні з естетичною 
освітою сприяє підвищенню як професійного, так і загальнокультурного рівня студентів; вивчення «Бізнес-етики», внаслідок іiі гуманістичного спрямування, сприяє ознайомленню з цивілізованими методами ведення бізнесу, управління, налагодження відносин та виробленню вмінь та навичок прийнятної поведінки відповідно до усталених в суспільстві моральних норм, принципів і правил; «Конфліктологія» забезпечує формування та розвиток професійних якостей управлінця, що допоможуть уникати зайвої напруги у відносинах зі співробітниками, зробити їх гармонійними, спрямовувати потенційні конфлікти в конструктивне, ділове русло.

Формування професійних рис майбутніх управлінців, в ході викладання означених дисциплін, забезпечується поєднанням імітаційних та не імітаційних методів навчання. Серед основних імітаційних методів, які наближають навчальний процес до умов майбутньої професійної діяльності управлінця, є професійно-педагогічна проблемна ситуація, що моделює професійну діяльність менеджера і на її основі професійно й особистісно значущі якості, і яка дозволяє активізувати пізнавальну активність студента. Робота $з$ цим типом проблемних ситуацій не просто вимагає застосування отриманих знань на практиці, а й самостійності у прийнятті рішень, творчого підходу до ситуацій, ступінь складності яких зростає на різних етапах навчання. Установка здійснюється на формування у студентів необхідних знань, комунікативних умінь та навичок 3 урахуванням особливостей діяльності професіонала в управлінській сфері.

Зрозуміло, що використання професійно-педагогічних ситуацій здійснюється в поєднанні з інформаційними кейсами різного змістового наповнення, в тому числі і проблемного змісту; широко застосовуються тренінгові програми, які дозволять відпрацювати необхідні фахівцю вміння та навички. Тренінгові програми містять різнопланові завдання, починаючи від діагностичних, які дають можливість встановити наявний стан розвиненості тієї чи іншої професійної якості, i, закінчуючи різноманітними техніками, що покликані забезпечити удосконалення професійних вмінь та навичок: це і різноманітні творчі завдання та вправи, дискусії, бесіди, ділові ігри, «мозковий штурм» тощо.

Велике значення надається i не імітаційним методам, зокрема, виробничій практиці, під час проходження якої студенти мають змогу застосувати отримані знання та навички, спробувати себе в якості фахівця. Аналіз набутого досвіду, його оцінка як позитивного чи негативного повинні стати об'єктом роботи творчих проблемних груп. Створення постійних або тимчасових проблемних груп (від трьох до восьми осіб), дозволяє здійснювати активний пошук варіан- 
тів вирішення проблем управлінської діяльності. Цей метод буде ефективним за умови дотримання наступних вимог: проблема, яка обговорюється, справді важлива; спілкування повинно відбуватися у вигляді діалогу; кожен має право вільно висловлювати свою думку, але не нав'язувати іiі іншим; спільне прийняття рішення. Головне створити атмосферу взаємоповаги та довіри, що, 3 одного боку, стимулюватиме творчість студентів, дозволить перевірити на практиці набуті знання, а $з$ іншого - сприятиме засвоєнню навичок гуманістичного спілкування в колективі.

Отже, у пошуках оптимальних методів навчання, які б забезпечили формування активних суб'єктів економічної діяльності, ми зупинилися на застосуванні активних методів (імітаційних та не імітаційних), серед яких особливе місце посідає професійно-педагогічна ситуація. Використання професійно-педагогічних ситуацій дозволяс реалізувати викладені теоретичні позиції на грунті вирішення проблеми формування особистості майбутнього фахівця як результату соціально-педагогічної практики у вищій школі. Причому, студент повинен усвідомлювати, що вирішення будь-якої проблемної ситуації супроводжується прогнозуванням, суб'єктивними оцінками, досвідом попередніх контактів. Такого досвіду, безперечно, студент повинен набути у стінах закладу вищої освіти.

\section{Література:}

1. Освітні технології : навчально-методичний посібник / заг. ред. О. М. Пехоти. Київ : А.С.К., 2001. 256 с.

2. Ковальчук Г. О. Активізація навчання в економічній освіті : навч. посібник. Київ : КНЕУ, 1999. 128 с.

3. Падалка О. Інтенсивні освітні технології. Вища освіта Украӥни. 2002. № 2. C. 91-95.

4. Шевчук С. П. Інтерактивні технології підготовки менеджерів : навч. посібник / С. П. Шевчук, В. А. Скороходов, О. С. Шевчук. Київ : Видавничий Дім «Професіонал», 2010. 232 с.

5. Ягоднікова В. В. Інтерактивні форми і методи навчання у вищий школі : навч.-метод. посіб. Київ : Персонал, 2009. 80 с. 